\title{
AN ANALYTICAL MODELLING APPROACH TO ASSESS THE APPLICABILITY OF GREEN CHAIN OPERATIONS: A CASE STUDY FROM THE SRI LANKAN APPAREL INDUSTRY
}

\author{
*R.S.W.B.S.M Ranatunga ${ }^{1}$, ${ }^{*}$ Thashika D. Rupasinghe ${ }^{2} \& *$ Nirmala Liyanaarachchi $^{3}$ \\ *Department of Industrial Management, University of Kelaniya, Sri Lanka
}

\begin{abstract}
Adopting 'green' practices have become synonymous with achieving long-term sustainability and many companies attempt to add value by adding "green" practices to their supply chains. However, manufacturers and suppliers are often hesitant to adopt green supply chain practices owing to the fear of incurring huge initial investments. To address the above issues, companies need a performance measurement framework to evaluate the applicability of Green Supply Chain Management (GSCM) practices in their industry. The Sri Lankan apparel industry is on the verge of embracing the GSCM practices into their supply chain processes. The objective of this study is to provide a framework to evaluate the applicability of GSCM practices in the Sri Lankan apparel industry from the operations management standpoint. Applicability is measured using performance measurement tools such as Balanced Scorecard (BSC) and Analytical Hierarchical Process (AHP) analysis. The proposed framework maps the key performance indicators hand-in-hand balancing economic performance and GSCM practices. Data collection was carried out from leading apparel manufacturers in Sri Lanka and the outcomes of this research helps determine the applicability of GSCM practices for Sri Lanka to yield economical, sustainable, and environmental benefits.
\end{abstract}

Keywords: Analytical Hierarchical Process, Apparel Industry, Balanced Scorecard, Green Supply Chain Management

\section{Introduction}

Sri Lankan apparel industry is one of the significant and dynamic contributors for the Sri Lankan economy, with a large contribution to the employment as well as foreign exchange earning within the country. The apparel industry is the second biggest contributor in Sri Lankan factory industry, behind the food and beverage production in the Factory Industry Production Index for 2015 (Central Bank of Sri Lanka, 2016). The supply chain of Sri Lankan apparel manufacturing process begins with the raw material, which is mostly supplied by foreign countries in order to maintain the quality of the product. Each apparel manufacturing organization comprises of multiple functional domains such as manufacturing, planning, and marketing. Sri Lankan apparel industry mostly behaves as a unit of a larger supply chain. (Perry et.al., 2012)

Operations for apparel production involves assembly, cut, make, and trim processes. Most apparel manufacturers cut and sew woven or knitted fabric, or knit apparel directly from yarn. Certain manufacturers perform cutting or sewing operations on material owned by another entity. Most apparel manufacturers have utilized lean manufacturing and modular systems for manufacturing operations. The manufacturers can decide on outsourcing the textiles from another establishment, or make the textile components in - house. All companies which have apparel manufacturing plants are intending to improve the efficiency to reduce the production lead 
time. intended to going under higher efficiency its help to reduce production lead time.

Green supply chain management means adding "green" component to the company supply chain. (Lakshmi Meera et.al., 2013). There are three large scale Sri Lankan apparel manufactures which have introduced the green concept to their supply chains. However, the adoption of green practises in the above cases has been limited to wastage reduction (De Silva and Rupasinghe, 2016). Integrating green design or green manufacturing is still at an introductory level. The major reason behind this slow adoption of green practises in design and manufacturing was balancing supply chain at a low cost and being innovative to substantiate both environmental and economic sustainability which became a major challenge (Pagell, 2004, Liyanage and Rupasinghe, 2016). Environmental practises in Supply Chain Management (SCM) pose inherent complexity during adoption due to multiple stakeholders, uncertain implications and international presence, and have been a challenging field for researchers. GSCM research so far can be considered ad hoc, fragmented and partial (Lakshmimeera et.al., 2013).

Sri Lankan apparel manufacturers face the aftereffects of transferring GSCM into their process. The cost of implementing GSCM practises is considerably high, and can rise further in the future if they are not properly managed. Furthermore, these practises involve a degree of uncertainty regarding market position, stakeholder concerns, and change. However, GSCM can reduce the ecological impact of industrial activity without sacrificing quality, cost, reliability, performance or energy utilization efficiency (Cooray and Rupasinghe, 2016). However the companies should identify the level of applicablity of green practises in Sri Lankan context, in order to achieve the aforementioned. If company shareholders see the benefits of applying GSCM to company processes, they will accept the changes. The companies currently utilizing GSCM will have a better opportunity to extend their applications. As such, the aim of this research is to find out the applicability of GSCM practises and how they can be used to improve company performance in apparel industry in Sri Lanka.
The research consists of following objectives;

- Study the current GSCM process and practises in Sri Lankan apparel manufacturing industry

- Identify current status of GSCM practises of Sri Lankan apparel industry as opposed to that of global apparel industry,

- Analyse the applicability of GSCM practises within Sri Lankan context,

- Identify the main GSCM practises that should be managed to obtain the necessary organizational performance that will affect the supply chain key performance indicators (KPIs),

- $\quad$ Find the extent to which the green practises can applied to supply chain in order to add value to the company

- Development of a framework with steps of applicable GSCM practises in Sri Lankan context which help non - green manufacturers to adopt GSCM.

The expected outcomes of the research are,

- Identification of GSCM practises in apparel manufacturing operations applicable as well as not applicable in Sri Lankan context,

- New GSCM practises which can be applied in Sri Lankan context and already used in other countries,

- A set of guidelines for non-green apparel manufacturers, as well as partially complete apparel manufacturers, to transform their supply chain into a GSC.

\section{Literature Review}

GSCM is defined as 'integrating environmental thinking into supply-chain management, including product design, material sourcing and selection, manufacturing processes, delivery of the final product to the consumers as well as end-of-life management of the product after its useful life' (Srivastva, 2007). It can also be defined as 'the integration of both environmental and supply chain managements and has been identified as a proven way to reduce an organization's impact on the environment while improving business performance' (Torielli et al., 2011). 
Green manufacturing and remanufacturing is a very important area within green operation. In 2008, Carvalho defined green operational practises such as reduction of redundant and unnecessary materials, reduction of replenishment frequency, integration of the reverse material and information flow in the supply chain environmental risk sharing, waste minimization, reduction of transportation lead time, and efficiency of resource consumption (Carvalho and Cruz-Machado, 2008). Furthermore, green operational practises can also be defined as product design to use reduced material/energy, with ability to reuse/recycle/recover, which ensures no/less hazardous material/process, and supports environmental regulations (Lakshmimeera et.al., 2013).

The aforementioned definitions of GSCM imply that simply 'being green' will not be adequate for modern organizations. Bowenet et. al., (2001) stated that organizations will adopt GSCM practises if they identify that such an adoption will result in specific financial and operational benefits. The 'greening' of supply chain is also influenced by the following processes' characteristics process capability to use certain materials, possibility to integrate reusable or remanufactured components into the system (which would require disassembly capacities), and design for waste minimization (energy, water, raw materials, and non-product output) (Sarkis, 2003).

Beamon (1999) identified present performance measures appropriate for the Green supply chain. These measurements are identified using International Organization for Standardization (ISO) adopted ISO 14000 Series as its international specification standard for environmental management system. The ISO 14000 Series documentation comprises of five basic components, and is structured as shown in Table 1 below;
Table 1: The ISO 14000 Series (source: International Organization for Standardization, 1996)

\begin{tabular}{|c|c|}
\hline ISO family & Requirement \\
\hline ISO 14001 & $\begin{array}{lr}\text { Specifies } & \text { minimum } \\
\text { requirements } & \text { for } \\
\text { achieving ISO } 14000 \\
\text { Certification }\end{array}$ \\
\hline ISO 14004 & $\begin{array}{l}\text { Sets guidelines for } \\
\text { developing an } \\
\text { environmental auditing }\end{array}$ \\
\hline ISO 14010 & $\begin{array}{l}\text { Establishes the general } \\
\text { principles } \\
\text { environmental auditing }\end{array}$ \\
\hline ISO 14011 & $\begin{array}{l}\text { Establishes auditing } \\
\text { procedures for the } \\
\text { auditing of Enterprise } \\
\text { Management systems }\end{array}$ \\
\hline ISO 14012 & $\begin{array}{l}\text { Establishes qualification } \\
\text { criteria for environmental } \\
\text { auditors }\end{array}$ \\
\hline
\end{tabular}

Corporate performance measurement and its applications continue to grow and encompass both quantitative and qualitative measurements and approaches. The variety and level of performance measures largely depend on the goal of the organization or the characteristics of individual strategic business unit. This paper has defined a list of measures and metrics which are applicable for performance measuring. Furthermore, it identifies a set of existing measurement tools for GSCM/Performance Measurement System (PMS) (Table 2). 
Table 2: Comparison between GSCM performance measurement tools (source: Hervani et al., 2005)

\begin{tabular}{|c|c|c|}
\hline $\begin{array}{l}\text { GSCM/PMS } \\
\text { tools }\end{array}$ & Reference & Applicability of function in concern \\
\hline $\begin{array}{l}\text { Life cycle } \\
\text { analysis } \\
\text { type tools } \\
\text { (Faruk et al. } \\
\text { 2002) }\end{array}$ & $\begin{array}{l}\text { Venkatasubbaiah et } \\
\text { al., } 2014\end{array}$ & $\begin{array}{l}\text { Maps graphically represent the values of the environmental } \\
\text { impacts along the supply chain. The tool can evaluate various } \\
\text { products for comparison. }\end{array}$ \\
\hline $\begin{array}{l}\text { Balanced } \\
\text { Scorecard } \\
\text { (Kaplan } \\
\text { and Norton, } \\
\text { 1992, 2004) }\end{array}$ & $\begin{array}{l}\text { Chen et al. } 2008 \text {, } \\
\text { Jalali Nainiet al, } \\
2011 \text {, } \\
\text { Bhattacharya, } 2013\end{array}$ & $\begin{array}{l}\text { Feedback on internal business processes and external outcomes } \\
\text { in order tocontinuously improve strategic performance and } \\
\text { results. } \\
\text { Fulfils the requirement of ISO 14031, to focus on management } \\
\text { of the organization by objectives, to use as an information } \\
\text { system, to visualize the cause and effect relationships between } \\
\text { different measures. } \\
\text { BSC does not separate cause and effect over time: The time } \\
\text { dimension is not part of the BSC (Lee et al., 2008, Cebeci, } \\
\text { 2009) } \\
\text { BSC does not provide mechanisms for selecting best measures } \\
\text { of performance (Cebeci, 2009, Leung } \text { et al., 2006) }\end{array}$ \\
\hline $\begin{array}{l}\text { Analytical } \\
\text { hierarchy } \\
\text { process (Saaty } \\
\text { 1980) }\end{array}$ & $\begin{array}{l}\text { Handfield } e t \\
\text { al.,2002, } \\
\text { Pineda-Henson } e t \\
\text { al., 2002, } \\
\text { Sarkis., 1998, } 2003\end{array}$ & $\begin{array}{l}\text { Decision support model the extension of analytical hierarchy } \\
\text { process beyond dyadic organizational boundaries to further } \\
\text { supply chain evaluation has not been completed. }\end{array}$ \\
\hline $\begin{array}{l}\text { Data } \\
\text { envelopment } \\
\text { analysis tool } \\
\text { (Charnes et } \\
\text { al.,1978) }\end{array}$ & $\begin{array}{l}\text { Sarkis and Talluri, } \\
2004\end{array}$ & $\begin{array}{l}\text { A robust quantitatively focused benchmarking and performance } \\
\text { measurement tool } \\
\text { Inclusion and evaluation of environmental characteristics has yet } \\
\text { to be completed. }\end{array}$ \\
\hline $\begin{array}{l}\text { Analytic } \\
\text { network process } \\
\text { (ANP) (Saaty, } \\
\text { 1996) }\end{array}$ & Bhattacharya, 2013 & $\begin{array}{l}\text { A multi-criteria decision-making tool. } \\
\text { Strategic level decision making } \\
\text { Focus inner dependence, and among different sets of elements, } \\
\text { outer dependence }\end{array}$ \\
\hline Game Theory & $\begin{array}{l}\text { Zhu and Dou, 2007, } \\
\text { Chen and Sheh, } \\
2009\end{array}$ & Strategic level decision making \\
\hline Fuzzy theory & Bhattacharya, 2013 & $\begin{array}{l}\text { Fuzzy sets are able to resemble human decisions. Fuzzy } \\
\text { triangular numbers transform the qualitative linguistic } \\
\text { preferences into quantitative forms. }\end{array}$ \\
\hline
\end{tabular}


Extensions to the balanced scorecard to incorporate environmental performance measures have also been significantly advanced (Epstein and Wisner, 2001, Zingales et al., 2002) (Figure 1). In the conclusion, US Environmental Protection Agency identified the balanced scorecard approach as their methodology for deploying strategic direction, communicating expectations, and measuring progress towards agreedto objectives (Kanji, 2003).

\section{Financial}

- Percentage of proactive vs. reactive expenditures

- Capital investments

- Operating expenditures

- Disposal costs

- Recycling revenues

- Revenues from "green" products

- Fines and penalties

- Cost avoidance from environmental actions

\section{Customer}

- Number of green products

- Product safety

- Number of recalls

- Customer returns

- Unfavourable press coverage

- Percentage of products reclaimed after use - functional product eco-efficiency

\section{Internal process}

- Percentage of production and office materials

- certified suppliers

- Number of accidents and spills

- Internal audit scores

- Energy consumption

- Percentage of facilities certified

- Percentage of product remanufactured

- Energy use

- Greenhouse gas emissions

- Hazardous material output Learning and growth

- Percentage of employees trained

- Percentage of renewable resource use

- Number of

- Community reported by employees

- Employees with incentives related to

- environmental goals

- Functions with environmental responsibilities

- Emergency response programs

Figure 1: Environmentally based performance measures by the balanced scorecard categories (source: Epstein and Wisner, 2001)

Balanced scorecard can be integrated with other performance tools to evaluate the performance;

Table 3: Integration of Balanced Scorecard with other tools for performance evaluation

\begin{tabular}{ll}
\hline Tool & Reference \\
\hline Fuzzy Analytic Hierarchy Process (AHP) & Lee, Chen, and Chang, 2008 \\
\hline Data envelopment analysis & Yuan and Chiu, 2009 \\
\hline Case based reasoning & Yuan and Chiu, 2009 \\
\hline Quality function deployment & Cohen, 2011 \\
\hline Multi - attribute utility theory & Stward and Mohamed, 2001 \\
\hline Analytic Network Process (ANP) & Ravi, Shankar, and Tiwari, 2005 \\
\hline Fuzzy ANP & Tseng, 2010, Yüksel and Dağdeviren, 2010 \\
\hline Fuzzy Delphi method and ANP & Hsu et al. 2011 \\
\hline Game theory & Jalali Naini et al., 2011 \\
\hline
\end{tabular}


Fuzzy (AHP) with BSC approach framework provides a mechanism for calculating the relative weights for each performance measure (Wuet al., 2009). While AHP is used to structure the hierarchy and relative weightings of performance perspectives, and indicators and measures (Stwart and Mohamed,

2001, Lee, Chen, and Chang, 2008) within the BSC framework, it does not consider the interdependencies, using a network, of the causal relationship meant for Green BSC (GrBSC). ANP considers the interdependencies among criteria, subcriteria and determinants. BSC can be successfully used for managing environmental aspects of performance (Länsiluoto and Järvenpää, 2010, Wynder, 2010). ANP is a qualitative multi-attribute decision-making approach providing structured communication to address m-business problems.

Chandraker and Kumar (2013) analyse the effects of individual activities (GSCM practises) and $t$ corresponding contribution towards economical and environment performance. In this paper MCDM (Multi Criteria decision making) model is used to determine GSCM performance, with the help of the parameters related to GSCM performance. AHP method is applied to determine the weight of all parameters.

Bhattacharya (2013) developed a collaborative decision-making approach. This paper demonstrates how a green-balanced scorecard (GrBSC) method is developed and implemented for a UK based carpetmanufacturing company in order to measure SC performance within a CDM (collaborative decisionmaking) environment.

Carter and Rogers (2008) and Carter and Easton (2011) describe the broad view of sustainability incorporating the concepts of economic, social, and environmental performance. It is important to know whether there is an economic advantage in adopting GSCM.

Rao et al., (2005) developed a model to figure out whether GSC really benefits the organization in an economic perspective. Samples were taken by
ISO14001 certified companies in South East Asia. This research investigated the relationship between GSCM practises (inbound logistics, production or the internal supply chain, outbound logistics, and in some cases, reverse logistics, including and involving materials suppliers, service contractors, vendors, distributors and end users working together to reduce or eliminate adverse environmental impacts of their activities), competitiveness (improved efficiency, quality improvement, productivity improvement, and cost savings), and economic performance (new market opportunities; product price increase; profit margin; sales; and market share).

Lakshmi Meera and Palanisamy (2014) proposed a model to evaluate whether there is a positive relationship between GSCM practises and environmental performance in manufacturing industry in Tamil Nadu, India.

\section{Method and Materials}

The research is based on two approaches. First focuses on the basic research. In the basic research the GSCM practises currently used in apparel manufacturing supply chain operations in Sri Lanka are analysed. This provides an answer to the fundamental question about what GSCM practises they are practicing and their feasibility. In the second phase of the research, which is applied research, the applicability of these GSCM practises in to SME Apparel Company in Sri Lanka is investigated. Afterwards, a generic framework which gives sequence of most applicable practises to adopting traditional SC to GSC for operational process in apparel manufacturing company in Sri Lanka is developed. The research is based on scientific approach. It measures the relationship between current GSCM practises and organization performance to find out whether these practises have a positive relationship on organization performance or not. Therefore, correlational research approach will be conducted.

Following table lists the definitions required to carry out the research. The research is conducted according to these definitions (Table 3). 
Table 3:Construct definitions

\begin{tabular}{ll}
\hline Construct & Definition \\
\hline Green Supply chain Management & $\begin{array}{l}\text { GSCM is the practise of monitoring and improving } \\
\text { environmentalperformance in the supply chain with ISO } \\
14001 \text { or any EMP system )Godfrey, 1998( }\end{array}$ \\
\hline Brown Supply Chain Management & Brown SCM is the SC which in introductory level of \\
& GSCM practises and monitoring without proper EMP \\
\hline Operations process in Sri Lankan & Inbound logistics which include Tailoring, sewing, ironing \\
Apparel Industry & and packing function) .ShoufengJi, Yuran Jin, Campbell, \\
& 2014( \\
\hline SME Apparel company in Sri Lanka & Small -Monthly Turnover )Rs. million(<5 and Number of \\
& $\begin{array}{l}\text { Employees < 100 } \\
\text { Medium -Monthly Turnover )Rs. million( between 5 - } \\
\text { 200 and Number of Employees between 100 -500 } \\
\text { Large -Monthly Turnover )Rs. million(>200 and Number } \\
\text { of Employees }>500\end{array}$ \\
& )Source :Survey data, 2012( \\
\hline
\end{tabular}

Since the study focused on apparel industry in Sri Lanka, all the garment factories located within the boundaries of the country belong to the survey population. Sample frame include green, brown, and non-green apparel manufacturing companies. Within this sample frame, research is conducted on three sample units.

- Sample 1: Apparel manufacturing companies with GSCM (according to definition)

- Sample 2: Apparel manufacturing companies without GSCM

- Sample 3: Brown SC companies

Since only a handful of companies are capable of implementing GSCM, the first sample includes all green apparel companies in Sri Lanka. The companies are selected according to similarities of their supply chain strategies. This sample includes only three green (manufacturing) plants. Sample 2 includes all the other garment factories in Sri Lanka. Therefore, due to practical difficulties in investigating all the elements in the population, a representative sample of 10 garment factories which have not implemented GSCM were selected through cluster sampling technique. The sample consisted of LS, MS and SS garment factories in Sri Lanka. Furthermore, sample three includes all brown SC apparel companies.

Data were gathered from both primary and secondary method. Primary data were gathered from interviews and questionnaires/ field surveys. In order to facilitate the survey, a structured questionnaire was designed and developed after a rigorous literature review. For scoring purposes, a 5 point Likert scale was employed, with the score of 1 relating to strong disagreement and 5 reflecting strong agreement. Secondary data were gathered from Central Bank Annual Report, relevant journal articles, web resources, and other forms of media.

To validate the research, an instrument was selected after the literature review. According to Hervani et al. (2005), balanced scorecard became the most suitable current performance measurement tool. When developing key performance indicators to measure the performance of GSCM practises, current KPI was also counted. Therefore, face and content validity were protected. Internal consistency of instruments in the questionnaire was measured using Cronbatch's Alpha coefficient. Hypotheses were developed with respect to the research questions. After finding the best practises, they were cross validated with the SME garment which did not utilize GSC, and with the brown SC companies. BSC was used again for this validation. The Kruskall Wallis test was conducted to find out the differences in the population.

\section{Results}

Interviews were carried out with general managers, quality managers, operation managers, and assistant managers in green plants, regarding waste minimization, efficiency of resource consumption, 
reduced carbon emission in production, energy efficient tools/machines, clean technology, biodiversity refuge, and energy conservation.

The practises already implemented in operations level were identified before. An index system that adapts to the whole performance evaluation of garment manufacturing green supply chain is constructed in the research. The system consists of 4 level indicators and 26 secondary indicators.
To determine the relative weights, managers were asked to make pairwise comparisons using a preference scale, similar to the scale in Table 4. For instance, if finance is judged to be "very strongly more important" than customer in supporting the business strategy, a score of 7 is given.

Table 4 Scale of the Preferences

\begin{tabular}{ll}
\hline Verbal judgment & Degree of preference \\
\hline Equally preferred & 1 \\
\hline Moderately preferred & 3 \\
\hline Strongly preferred & 5 \\
\hline Very strongly preferred & 7 \\
\hline Extremely preferred & 9 \\
\hline
\end{tabular}

Note: Intermediate levels can be used to provide additional levels of discrimination

\section{Pairwise comparison}

In this comparison, AHP analysis of judgments of several people in the assessment process was taken. This is a critical issue, since determining the relative importance of the competitive priorities, and of the performance measures is normally a collective process that may involve several managers and management accountants. Therefore, to gather relevant data, the survey was distributed among general manager, quality manager, and assistant mangers of the concerned companies. In order to consider the AHP the judgments of several people to aggregate the individual paired judgments on the basis of a mathematical operator like, for instance, the geometric mean is used.

After the qualitative data were transferred to quantitative data, Figure 2 shows the decision tree for each factor. The following decision tree can be used to identify the most suitable green practise as shown in figure. 


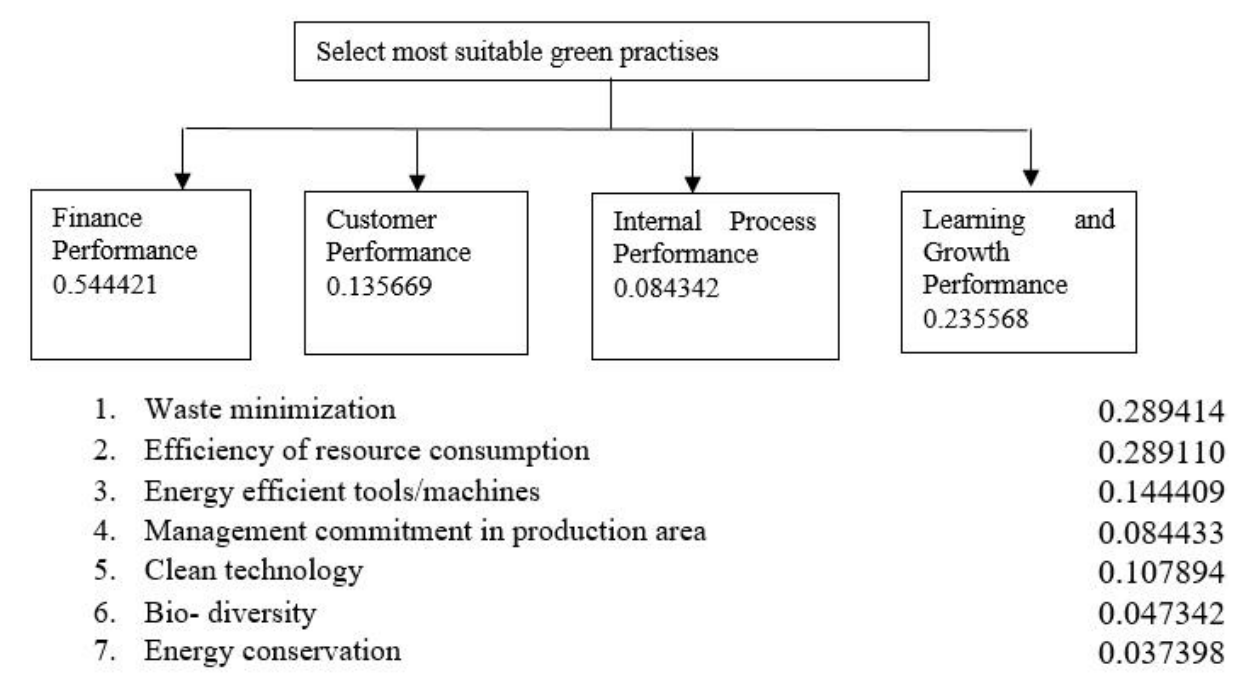

Figure 2: Calculated decision tree

\section{Analysis of Internal Consistency}

Cronbatch's Alpha coefficient was used in order to identify the internal consistency of the instruments represents the Cronbatch's Alpha values of the instruments. The result suggested that the instruments used to measure the above green practises of GSCM. According to statistics, there is a high internal consistency in all the instruments when Cronbatch's Alpha coefficient is greater than 0.7. Following table possessed a high degree of internal consistency (Table5).

Table 5: Cronbatch's Alpha values of instruments

\begin{tabular}{ll}
\hline Instrument & Values \\
\hline Green Plant & 0.792 \\
\hline Waste minimization & 0.704 \\
\hline Efficiency of resource consumption & 0.916 \\
\hline Energy efficient tools/Machines & 0.609 \\
\hline Management commitment in production area & 0.789 \\
\hline Clean technology & 0.849 \\
\hline Bio- diversity & 0.951 \\
\hline Energy Conservation & \\
\hline Non-green Plant & 0.696 \\
\hline Waste minimization & 0.702 \\
\hline Efficiency of resource consumption & 0.744 \\
\hline Energy efficient tools/Machines & 0.689 \\
\hline Management commitment in production area & 0.869 \\
\hline Clean technology & 0.756 \\
\hline Bio- diversity & 0.802 \\
\hline Energy Conservation & 0.855
\end{tabular}


Testing hypotheses for green plant

After finding the weight factors for each measurement, it is required to find the green practises performed in the plant. Therefore, hypotheses test is carried out for testing the relationship between each practise (Table 6).

Table 6: Hypotheses for testing relationships between green practises

\begin{tabular}{ll}
\hline Area of Concern (Hypotheses) & Variables in Concern \\
\hline Waste minimization and green plant $\left(\mathrm{H}_{1}\right)$ & $\mathrm{a}$ - Finance performance \\
\hline Efficiency of resource consumption and green plant $\left(\mathrm{H}_{2}\right)$ & $\mathrm{b}$ - Customer performance \\
\hline Energy efficient tools/Machines and green plant $\left(\mathrm{H}_{3}\right)$ & $\mathrm{c}$ - Learning and growth performance \\
\hline $\begin{array}{l}\text { Management commitment in production area and green plant } \\
\left(\mathrm{H}_{4}\right)\end{array}$ & $\mathrm{d}$ - Internal process performance \\
\hline Clean technology and green plant $\left(\mathrm{H}_{5}\right)$ & $\mathrm{e}$ - Overall performance \\
\hline Bio - diversity and green plant $\left(\mathrm{H}_{6}\right)$ & \\
\hline Energy conservation and green plant $\left(\mathrm{H}_{7}\right)$ & \\
\hline
\end{tabular}

Hypothesis test is done using Spearman's coefficient of rank correlation. It is described the relationship calculated for each hypothesis testing. Following shows the result of the hypothesis (Table 7)

Table 7: Green practises with their accepted hypothesis spearmen correlation values between sets of ranked data. Using SPSS Statistics 17.0 Spearman's coefficient of rank correlation was

\begin{tabular}{|c|c|c|c|c|c|}
\hline 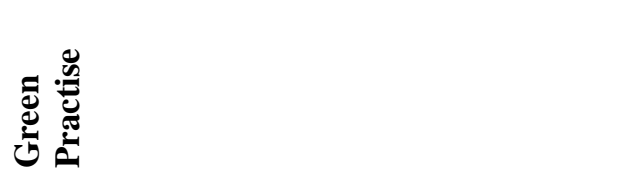 & ت & تُ & 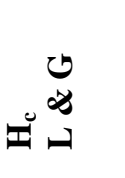 & 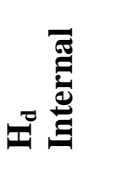 & ت \\
\hline Waste minimization & 0.858 & $\mathrm{X}$ & $\mathrm{X}$ & 0.621 & 0.782 \\
\hline Efficiency resource consumption & 0.723 & & $\mathrm{X}$ & 0.355 & 0.696 \\
\hline Energy efficient tools/machines & 0.636 & $\mathrm{X}$ & $\mathrm{X}$ & 0.769 & 0.630 \\
\hline $\begin{array}{l}\text { Management commitment in production } \\
\text { area }\end{array}$ & 0.232 & $\mathrm{X}$ & 0.5 & 0.921 & 0.644 \\
\hline Clean technology & 0.251 & 0.232 & 0.449 & 0.207 & 0.396 \\
\hline Bio- diversity & 0.214 & 0.680 & $\mathrm{X}$ & 0.487 & 0.210 \\
\hline Energy conservation & 0.774 & 0.504 & 0.770 & 0.212 & 0.586 \\
\hline
\end{tabular}


Spearman's correlation coefficient is a statistical measure of the strength of a monotonic relationship between paired data. According to Spearman's correlation, in above findings green practises are identified in three categories;

Table 8 Identified best practises in operations process
Following shows the best practises which are identified from the hypothesis (Table 8).

\begin{tabular}{ll}
\hline Type of the relationship & Green practise \\
\hline Strong (best practises) & Waste minimization \\
$(0.60-1.0)$ & \\
\cline { 2 - 2 } & Efficiency resource consumption \\
\cline { 2 - 2 } & Energy efficient tools/machines \\
\cline { 2 - 2 } $\begin{array}{l}\text { Moderate } \\
(0.40-0.59)\end{array}$ & Eanagement commitment in production area \\
\hline $\begin{array}{l}\text { Weak } \\
(0.00-0.39)\end{array}$ & Clean technology \\
\hline
\end{tabular}

After considering AHP and Hypothesis values, the following framework is developed. This framework is based on green apparel manufacturing companies in
Sri Lanka. It is used to evaluate the applicability of GSC practises in operation process in Sri Lanka (Figures 3 and 4). 
Ranatunga R.S.W.B.S.M et al./ An analytical modelling approach to assess the applicability....

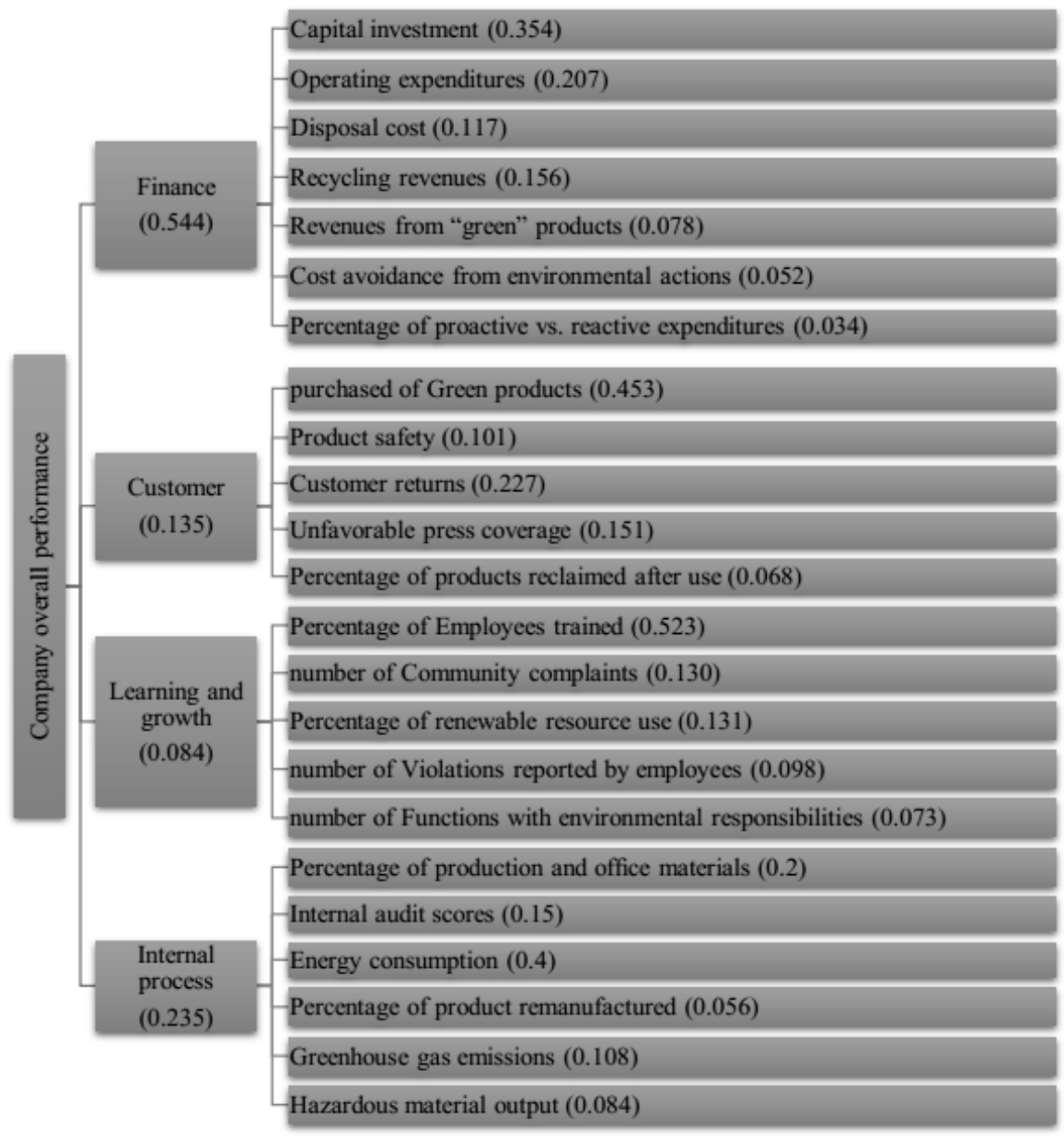

Figure 3: Model to measure the performance of the green practises performance in operation level

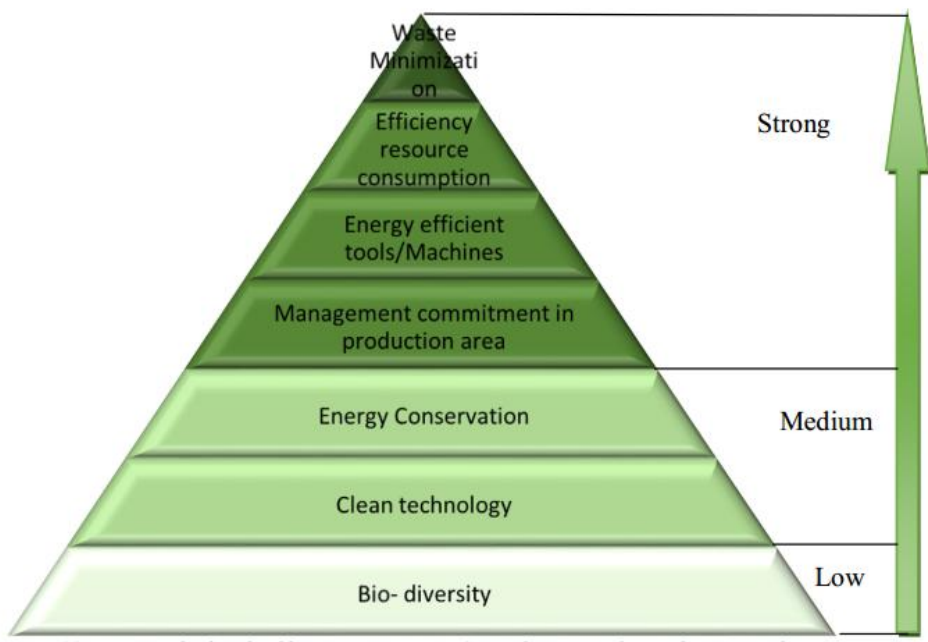

Figure 4: Framework of applicable green practises in Sri Lankan Apparel Manufacturing Industry 
Another survey was distributed to validate the above framework. This survey focused upon non- green apparel companies in Sri Lanka. The sample consisted of 10 large scale apparel companies, 10 medium scale companies and 10 small scale companies. This scale is selected according to the methodology. Kruskall - Wallis test was carried out to find whether the samples originated from the same distribution through a comparison of variances by ranks. Null hypothesis (H0) : There is no difference in the population distributions and alternate hypothesis (Ha) -There is a difference in the population distributions for this test are as follows.

Number of samples are 3 and each sample consists of 10 observations. With the significance level $(\alpha)$ of 0.05 , null hypothesis is not rejected and alternate hypothesis is rejected. Computed p-Value of $\mathrm{H}$ is greater than the significance level $(\alpha)$ or computed test statistic of $\mathrm{H}$ is less than critical value null hypothesis is rejected and alternate hypothesis is accepted if computed p-value of $\mathrm{H}$ is less than or equal to the significance level $(\alpha)$ or computed test statistic of $\mathrm{H}$ is greater than critical value.

Results show that the samples are different from each other for (null hypothesis is rejected) clean technology and biodiversity. When further categorizing, it is understood that only populations of medium and small scale companies are different from green plant population mean. Large scale companies have no difference in population with the green practises.

\section{Discussion}

The main objective of this research is to provide a framework to evaluate the applicability of green supply chain practises (operation process) in Sri Lankan apparel manufacturing industry. This research identified seven main practises related to operation level; waste minimization, efficiency resource consumption, energy efficient tools/machines, management commitment in production area, energy conservation, clean technology, and biodiversity. The overall performance of a given company is measured using predefined green balanced scorecard. A framework has been developed in order to find out the green practises applicable to Sri Lanka, and the extent to which they are applicable. Furthermore, a performance measurement model has been developed to measure performance of any upcoming green practises. Any given apparel manufacturing company can use this model to identify whether their green practises are applicable to Sri Lankan context or not.

For improved green supply chain performance, the customer needs to have a better understanding about GSC. Green products are comparatively expensive. A motivation factor should be present for the customer to spend in excess to buy a green product. It is important that an organization have good working relationships with their suppliers in order for it to successfully implement a green supply chain. Strong supplier relationships make it easier to engage with suppliers on environmental issues, to dictate instructions and standards based on environmental criteria, and to monitor suppliers using scorecards or risk assessment. Currently green practises are more focused on enhancing the finance performance and internal process performance. There are very few practises which involve with learning and growth performance. Researchers need to focus more on this area. Although finance and internal processes are more important for a particular company, it needs to consider other factors as well in order to increase the performance.

Furthermore, the research has shown that lean production has some features which positively affect the green concept. It is easier to convert lean company to green company. However, researchers are yet to discover from observation if lean production could be advantageous to GSCM. Therefore, Sri Lankan organizations involved in lean production can have the advantage of converting their SC to GSC. The company needs to focus more on reducing carbon emissions in micro level. At present this practise is only operating in macro level. However, if it also considers micro level, it will lead to the enhancement of company performance.

IT should be embedded to the operation process. IT is considered as a clean technology and it increases the efficiency of the process. Building an environment friendly platform for the industry will increase the performance of the company. 
This research can be extended to cover the entire supply chain. This research focused on operation level, but it could be extended to inbound/outbound sales and marketing. It will help to extract best practises related to GSC to improve the apparel industry. The performance measurement model which is developed in this research can be used to evaluate the best practises in other functions as well. It will help to identify the issues and limitations related to $\mathrm{SC}$, and this research can lead to extensive research to find out the relationship between green and lean strategy. Researchers have still not focused on this area. However, this is a research topic with high economic value. If the link between lean and green could be identified, that will be useful for garment factories which are currently following lean to adapt green practises in a shorter period.

\section{References}

Bhattacharya, A., Mohapatra, P., Kumar, V., Dey, P.K., Brady, M., Tiwari, M.K., and Nudurupati, S.S., 2014, "Green supply chain performance measurement using fuzzy ANP-based balanced Scorecard: a collaborative decision-making approach", Production Planning \& Control, 25(8), 698-714.

Boustead, I.H., 1979, Handbook of Industrial Energy Analysis, (Michigan: Ellis Horwood)

Beamon, B.M., 1999, "Designing the green supply chain", Logistics Information Management, 12(4), 332-342.

Bowen, F.E., Cousins, P.D., Lamming, R.C. and FARUK, A.C., 2001, The role of supply management capabilities in green supply. Production Operation Management, 10, 174-189.

Carvalho, H. and Cruz-Machado, V., 2011, Integrating Lean, Agile, Resilience and Green Paradigms in Supply Chain Management (LARG_SCM), 2011.

Central Bank Of Sri Lanka (2016) Annual Report 2015. Available at: http://www.cbsl.gov.lk/pics_n_docs/10_pub/_docs/ef r/annual_report/AR2015/English/content.htm

(Accessed 20 August 2016)

Chandraker, R., and Kumar, R., 2013, "Evaluation and Measurement of Performance of GSCM in Chhattisgarh Manufacturing Industries (INDIA)", International Journal of Application or Innovation in Engineering \& Management (IJAIEM), 2(1) ,240 249.

Carter, C. and EastoN, P., 2011, Sustainable supply chain management: evolution and future directions,
International Journal of Physical Distribution \& Logistics Management, 41(1), 46-62.

Carter, C. and Rogers, D., 2008, A framework of sustainable supply chain management: moving toward new theory, International Journal of Physical Distribution \& Logistics Management, 38(5), 360387.

Charnes, A., Cooper, W.W. and Rhodes, E., 1978, "Measuring the efficiency of decision making units", European Journal of Operational Research, 2, 429444.

Cohen, Y., 2011, "A New Technique for Evaluating the Balanced Scorecard Dashboard Values." Problems and Perspectives in Management 9 (1) 7884.

Cooray P.L.N.U.A and Rupasinghe, T.D., 2016, “An Analysis of Green Vehicle Routing Problem (GVRP) Solving Methodologies: A Systematic Review of Literature", Research for Transportation and Logistics Industry (R4TLI), Colombo, Sri Lanka, June2016.

De Silva R. K. J., and Rupasinghe T D., 2016, Characterization of New Product Development (NPD) Models Applicable to enhance the overall performance of the Apparel Industry, International Journal of Textile and Fashion Technology, 6(3).

Epstein, M.J., and Wisner, P.S., 2001, "Good neighbors: implementing social and environmental strategies with BSC", Balanced Scorecard Report, Harvard Business School Publishing, Cambridge, MA, 2001

Faruk, A.C., Lamming, R.C., Cousins, P.D. and Bowen, F.E., 2002, "Analyzing, mapping, and managing environmental impacts along supply chains", Journal of Industrial Ecology, 5(2), 13-36.

Gustafson, A., Schmiesing-Korff, A. and NG, S., 2004, A time efficient supply chain model for an Apparel Company, MBA. University of Kristiansand.

Handfield, R., Walton, S.V., Sroufe, R. and Melnyk, S.A., 2002, "Applying environmental criteria to supplier assessment: a study in the application of the analytical hierarchy process", European Journal of Operational Research, 141, 70-87.

Hervani, A.A., Helms, M.M., and Sarkis J., 2005, "Performance measurement for green supply chain management," Benchmarking: An International Journal, 12(4), 330-353.

Hoshino, T., Yura, K. And Hitomi, K., 1995, "Optimization analysis for recycle-oriented manufacturing systems", International Journal of Production Research, 33, 2069-2078.

Hsu, C.W., Hu, A.H., Chiou, C.Y., and Chen, T.Y., 2011, "Using the FDM and ANP to Construct a Sustainability Balanced Scorecard for the 
Semiconductor Industry.", Expert Systems with Applications 38 (10): 12891-12899.

Jalali Naini, S.G., Aliahmadi A., and JafariEskandari, M., 2011, "Designing A Mixed Performance Measurement System for Environmental Supply Chain Management Using Evolutionary Game Theory and Balanced Scorecard: A Case Study of an Auto Industry Supply Chain". Resources, Conservation and Recycling, 55(6), 593-603

Kanji, G.K., 2003, “A new business excellence model from an old Indian philosophy”, Abinngdon, 14(9), 1071.

Kaplan, R.S, and Norton, D.P., 1996, Using the balanced scorecard as a strategic management system, Harvard Business Review, 74(1), 75 - 85.

Kaplan, R.S, and Norton, D.P., 2004, Strategy maps: converting intangible assets into tangible outcomes. (Boston, MA: Harvard Business School Press).

Green, K.W., Zelbst, P.J., Meacham, J., and Bhadauria, V.J., 2012, "Green supply chain management practises: impact on performance", Supply Chain Management: An International Journal, 17(3) 290-305

Lakshmi Meera, B.L., and Palanisamy. C., 2013, “A Conceptual Framework on Green Supply Chain Management Practises", Industrial Engineering Letters, 3(10)

Lakshmi Meera, B.L., and Palanisamy. C., 2014, "Environmental Sustainability through Green Supply chain management practises among Indian Manufacturing Firms with special reference to Tamil Nadu", International Journal of Scientific and Research Publications, 4(3).

Länsiluoto, A., and Järvenpä Ä, M., 2010. “Greening the Balanced Scorecard." Business Horizons 53 (4): 385-395.

Lee, J.J., O'callaghan, P. and AlleN, D., 1995, Critical review of life cycle analysis and assessment techniques and their application to commercial activities, Conservation and Recycling, 13, 37-56.

Lee, A. H. I., Chen, W.C., and ChanG, C.J., 2008, “A Fuzzy AHP and BSC Approach for Evaluating Performance of IT Department in the Manufacturing Industry in Taiwan." Expert Systems with Applications 34 (1), 96-107.

31. LEE, M. S., KIM, S.T., and CHOI, D., 2012, "Green supply chain management and organizational performance", Industrial Management \& Data Systems 112(8), 1148-1180.

Linnhoff, B., 1993, Pinch analysis: a state-of-the-art overview, Transactions of Chemical Engineering, 71(A), 503-522.

Liyanage R.P., and Rupasinghe T.D., 2016, An Analytical Model Formulation to Enhance the Green
Logistics (Gl) Operations: From the Perspective of Vehicle Routing Problem (VRP), American Journal of Engineering Research (AJER), 5(8), 294- 299.

Pagell, M., and Wu, Z., 2009, "Building a more complete theory of sustainable supply chain management using case studies of 10 exemplars", Journal of Supply Chain Management, 45(2), 38-56.

Pineda-Henson, P., Culaba, A.B. and Mendoza, G.A., 2002, "Evaluating environmental performance of pulp and paper manufacturing using the analytic hierarchy process and life cycle assessment", Journal of Industrial Ecology, 6(1), 15-28.

Rao, P., and Holt, D., 2005, "Do green supply chains lead to competitiveness and economic performance?", International Journal of Operations \& Production Management 25(9), 898-916.

Ravi, V., Shankar, R., and Tiwari, M. K., 2005 "Analysing Alternatives in Reverse Logistics for End-of-Life Computers: ANP and Balanced Scorecard Approach." Computers and Industrial Engineering 48 (2): 327-356.

Saaty, T.L., 1980, The Analytical Hierarchy Process, (New York:McGraw-Hill).

Sarkis J., 1998, Evaluating environmentally conscious business practises. European Journal of Operational Research, 107(1), 159-174

Sarkis J., 2003, “A strategic decision framework for green supply chain management", Journal of Cleaner Production, 11 397-409.

Sroufe, R., 2003, “A framework for strategic environmental sourcing”, Greening the Supply Chain. Sheffield:Greenleaf.

Srivastva, S., 2007, "Green supply chain management: A state of the art literature review", International Journal of Management Review, 9(1), 53-80.

Stwart R. A., and Mohamed S., 2001, "Utilizing the Balanced Scorecard for IT/IS Performance Evaluation in Construction." Construction Innovation 1 (3), 147-163.

Tseng, M.L., 2010, "Implementation and Performance Evaluation using the Fuzzy Network Balanced Scorecard." Computers \& Education 55 (1): 188-201.

Torielli, R.M., Abrahams, R.M., Smillie, R.W. and Voigt, R.C., 2011, "Using lean methodologies for economically and environmentally sustainable foundries", China Foundry, 8(1), 74-88.

Venkatasubbaiah K., Arun K., Badshah S.B.V.J.C., Gopalam.K., Narayana K., 2014, "Investigating green supply chain management approaches using analytic network process", International Journal of Advanced Scientific and Technical Research, 4(2), 268 - 279. 
Yuan, F.C., and Chiu, C., 2009, A Hierarchical Design of Case-based Reasoning in the Balanced Scorecard Application, Expert Systems with Applications 36 (1): 333-342.

Yüksel, İ., and Dağdeviren, M., 2010, Using the Fuzzy Analytic Network Process (ANP) for Balanced Scorecard (BSC): A Case Study for a Manufacturing Firm. Expert Systems with Applications 37 (2): 1270-1278.

Wu, H.Y., Tzeng, G.H., and Chen, Y.H., 2009, A Fuzzy MCDM Approach for Evaluating Banking Performance based on Balanced Scorecard, Expert Systems with Applications 36 (6), 10135-10147.

Wynder, M., 2010, "Chemico: Evaluating Performance based on the Balanced Scorecard." Journal of Accounting Education, 28 (3-4), 221-236.
ZhU, Q., and SarkiS, J., 2004, "Relationships between operational practises and performance among early adopters of green supply chain management practises in Chinese manufacturing enterprises", Journal of Operations Management. 22, 265-289,

Zhu, Q., and Sarkis, J., 2004, The link between quality management and environmental management in firms of differing size: An analysis of organizations in China. Environmental Quality Management 13(3), 53-63.

Zingales, F., O'rourke, A. and Orssatto, R.J., 2002, "Environment and socio-related balanced scorecard: exploration of critical issues", working paper 2002/47/CMER, (Fontainebleau, France: INSEAD). 